A N N A L E S

UNIVERSITATIS MARIAE CURIE-SKŁODOWSKA

LUBLIN - POLONIA

VOL. LXXII, z. 2

SECTIO B

2017

Zakład Edukacji Geograficznej i Turystycznej

Wydział Nauk o Ziemi i Gospodarki Przestrzennej

Uniwersytet Marii Curie-Skłodowskiej

PAWEŁ WOJTANOWICZ, JOANNA SZCZĘSNA

\title{
Turystyka dzieci i młodzieży w Roztoczańskim Parku Narodowym jako element edukacji szkolnej
}

Tourism of children and young people in Roztocze National Park as an element of school education

Słowa kluczowe: Roztoczański Park Narodowy, turystyka, szkoła, edukacja środowiskowa

Keywords: Roztocze National Park, tourism, school, environmental education

"Let us teach about nature where nature is".

(F. Lutz, 1931)

\section{WPROWADZENIE}

Realizacja celów edukacyjnych z zakresu przyrody, biologii oraz geografii zawartych w Podstawie programowej ksztatcenia ogólnego... (2012, 2014, 2017) bez zajęć terenowych wydaje się niemożliwa. Warunki oraz sposoby realizacji zalecane w niniejszych dokumentach, zarówno w szkole podstawowej, gimnazjalnej, jak i ponadpodstawowej oraz ponadgimnazjalnej, wyraźnie wskazują na empirię jako podstawową drogę nauczania-uczenia się. Od uczniów wymaga się przeprowadzania doświadczeń, stosowania obserwacji, dokonywania pomiarów czy też eksperymentowania. Czynności te należy prowadzić nie tylko w najbliższym otoczeniu szkoły, ale także w miejscach oddalonych od niej, przede wszystkim w ramach wycieczek szkolnych, terenowych warsztatów dydaktycznych 
czy zajęć na ścieżkach dydaktycznych lub lekcjach kameralnych w ośrodkach edukacyjnych. Do miejsc spełniających wyżej wymienione wymogi zaliczyć możemy, między innymi: leśnictwa, skanseny, muzea oraz obszary chronione, w tym: rezerwaty, parki krajobrazowe i narodowe. Te ostatnie posiadają specyficzne walory środowiskowe, które należy nie tylko zachować dla potomności, ale także racjonalnie upowszechniać.

Celem niniejszego opracowania jest próba oceny oferty edukacyjnej Roztoczańskiego Parku Narodowego pod kątem jej przydatności w realizacji treści nauczania zawartych w Podstawie programowej kształcenia ogólnego... (2017). Punktem wyjścia podjętej analizy było przybliżenie - na podstawie literatury przedmiotu - roli terenowych form kształcenia w edukacji przyrodniczej. Ponadto, mając na uwadze zróżnicowanie intensywności działań ośrodków edukacyjnych funkcjonujących przy polskich parkach narodowych na rzecz edukacji środowiskowej społeczeństwa, dokonano zestawienia liczbowego organizowanych w nich wszelkiego typu wydarzeń dydaktycznych. Przegląd ten umożliwił orientacyjne porównanie usług z zakresu turystyki edukacyjnej Roztoczańskiego Parku Narodowego w odniesieniu do pozostałych parków narodowych w Polsce.

\section{ROLA ZAJĘĆ TERENOWYCH W EDUKACJI SZKOLNEJ}

Zajęcia terenowe są efektywnymi i bardzo lubianymi przez uczniów formami procesu dydaktyczno-wychowawczego szkoły. W wielu opracowaniach z zakresu dydaktyki ogólnej bądź dydaktyk przedmiotowych - zwłaszcza nauk przyrodniczych, (wymieńmy chociażby dydaktyki geografii) zarówno autorów odleglejszych współczesności, jak: W. Nałkowskiego (1908), S. Niemcówny (1929), S. Pawłowskiego (1933) czy B. Krugowskiego (1938), jak i tych bliższych: A. Chałubińskiej (1959), M. Czekańskiej (1963), G. Wuttkego (1963), Z. Batorowicza (1966), J. Winklewskiego (1966), W. i T. Łobożewicza (1978), E. Świtalskiego (1990), czy J. Kądziołki (1992) podkreśla się szczególne znaczenie obserwacji bezpośredniej. „Żadne opisy słowne i rysunki - jak pisał G. Wuttke - nie zastąpią bezpośredniej obserwacji na miejscu czynionej przez zaciekawione oczy, uczulone uszy" (za: I. Berne 1977). Wydaje się, że w naturalnym środowisku uczniowie chętniej wykonują takie czynności (w istocie rozwijają w sobie umiejętności), jak: poszukiwanie, gromadzenie, mierzenie, porównywanie, porządkowanie, analizowanie, badanie, stawianie hipotez i ich weryfikowanie, eksperymentowanie, ocenianie, wnioskowanie, przewidywanie czy wreszcie planowanie. Zajęcia w terenie - jak trafnie podkreśla K. Denek $(1996,1999)$ - są zatem nie tylko przygodą krajoznawczo-turystyczną i przyjemnością, ale przede wszystkim nauką poza ławką szkolną. Wspomniany wyżej autor określa tę formę 
zajęć jako „bezpośrednią, naturalną, radosną, zintegrowaną, opartą na działaniu, twórczym myśleniu i przeżywaniu, przeciwstawiającą się nauczaniu sformalizowanemu, werbalnemu, zachowawczemu, pamięciowemu i mechanicznemu" (za: Bochenek 2008). Poznawana w ten sposób rzeczywistość, przy dobrze obranej strategii kształcenia opartej przede wszystkim na aktywności ucznia, może być źródłem ich wątpliwości i wielu rodzących się w ich umysłach pytań. Są one z kolei dowodem na przyjmowaną przez uczniów postawę myśliciela i badacza (Szuman 1985). Łatwiej jest zatem poza murami szkolnymi zainteresować ucznia światem i rządzącymi nim prawami, a tym samym zaspokoić jego naturalną ciekawość.

W trakcie obserwacji terenowych, pod wpływem wielu bodźców, które bezpośrednio oddziałują na zmysły, zachodzą w umyśle dziecka złożone procesy percepcyjne, które z kolei odpowiedzialne są za wrażenia, spostrzeżenia i wyobrażenia. A to właśnie one stanowią podstawę rozwoju aparatu pojęciowego, którym posługuje się uczeń. Dodajmy fakt powszechnie znany, że im więcej zmysłów wykorzystywanych jest w procesie poznania, tym poznanie to jest pełniejsze, a przede wszystkim - trwalsze.

I. Janowski (2004) zwraca ponadto uwagę, że „wycieczki szkolne niezależnie od realizowanego programu edukacyjnego, kryją w sobie liczne aspekty filozoficzne i humanistyczne. Najważniejsze z nich ogniskują się wokół transcendentnej triady: prawdy, dobra i piękna. Każda z tych wartości wpływa na kształtowanie osobowości ucznia. Prawda doskonali intelekt, a dobro i piękno odpowiednio, wolę i uczucia". Można zatem przyjąć, że ponadprzedmiotowym założeniem zajęć terenowych powinno być: docieranie do prawdy o poznawanej rzeczywistości na podstawie aktywizacji wszystkich sfer poznawczych ucznia (także emocjonalnej) oraz czynienie dobra na rzecz tejże rzeczywistości. Zajęcia terenowe posiadają więc nieocenione wartości wychowawcze. W procesie wychowania - jak pisze W. Alejziak (2009) - „rozumianym jako całokształt wpływów i oddziaływań kształtujących rozwój człowieka oraz przygotowujących go do życia w społeczeństwie - jedną z kluczowych kwestii jest kształtowanie osobowości. Turystyka stwarza wiele możliwości oddziaływania na osobowość człowieka, gdyż towarzyszą jej zwykle: aktywność, wspólnota przeżyć, więzy koleżeństwa, odpowiedzialność, odwaga, zaradność itp."

Ponieważ zajęcia terenowe stanowią istotny element edukacji przyrodniczej, w Podstawie programowej kształcenia ogólnego... (2012, 2014, 2017) wyraźnie wskazuje się na nie jako obowiązkowe i integralne formy przeznaczone do realizacji celów kształcenia. Tematyka, którą należy opracować w terenie, wyraźnie zasygnalizowana jest dzięki odpowiednio sformułowanym wymaganiom ogólnym i szczegółowym. Poniżej przytoczonych zostanie kilka z nich. Już na 
pierwszym etapie edukacyjnym, w klasach I-III należy zadbać o to, aby zajęcia umożliwiały eksplorację środowiska przyrodniczego, a treści z zakresu edukacji przyrodniczej realizowane były między innymi poza szkołą w „,naturalnym” środowisku. Wymagania ogólne zobowiązują także nauczyciela do stworzenia strategii kształcenia prowadzących dziecko do zrozumienia konieczności dbania o środowisko przyrodnicze. W szkole podstawowej wśród osiągnięć z zakresu rozumienia środowiska przyrodniczego podkreśla się konieczność zetknięcia uczniów z terenem w celu wykształcenia umiejętności rozpoznawania popularnych gatunków roślin i zwierząt typowych dla miejsca zamieszkania. Z kolei „nadrzędnym celem przedmiotu przyroda w klasie IV jest przybliżenie uczniowi najbliższego otoczenia, stworzenie możliwości poznania składników krajobrazu i zależności zachodzących w przyrodzie”. W wyżej wymienionym dokumencie ministerialnym w uwagach o zalecanych warunkach i sposobach realizacji, w ramach tego przedmiotu wyszczególniono także główne obszary aktywności ucznia. Znalazły się tam, między innymi: prowadzenie obserwacji i pomiarów oraz wykonywanie doświadczeń. Ponadto, zadaniem ucznia jest projektowanie, na podstawie własnych obserwacji terenowych, działań służących zachowaniu walorów środowiska geograficznego (przyrodniczego i kulturowego) oraz poprawie warunków życia lokalnej społeczności.

Godny uwagi jest także zapis, że szkoła powinna zapewnić warunki do bezpiecznego prowadzenia przez uczniów prac badawczych oraz obserwacji terenowych koniecznych do realizacji niektórych wymagań. „Podczas tych zajęć - czytamy dalej w dokumencie - nauczyciel winien otrzymać wsparcie ze strony dyrekcji szkoły, władz samorządowych i społeczności lokalnej, a sam aktywnie uczestniczyć w tworzeniu odpowiednich warunków organizacyjnych do ich prowadzenia".

Założenia dotyczące zajęć poza budynkiem szkoły kontynuowane są w liceum między innymi na lekcjach geografii. W obowiązującej aktualnie Podstawie programowej kształcenia ogólnego... przy zalecanych warunkach i sposobach realizacji treści analizowanego przedmiotu czytamy: „wskazane jest w znacznie większym zakresie korzystanie z obserwacji bezpośrednich dokonywanych przez uczniów [...] oraz jak najczęstsze nawiązywanie do regionu, w którym uczeń mieszka”. W uczniu rozwijającym w sobie ciekawość świata, poprzez zainteresowanie własnym regionem, wzrasta „poczucie (bardziej świadomej) odpowiedzialności za środowisko przyrodnicze i kulturowe własnego regionu". Z kolei w Komentarzu do Podstawy programowej przedmiotu geografia podkreślono, że ,wycieczki i zajęcia w terenie powinny być obowiązującym, stałym i systematycznie stosowanym sposobem poznania geograficznego oraz kształtowania szeregu umiejętności. [...] Znajomość z autopsji własnego regionu powinna być 
podstawą do porównań z innymi, polskimi regionami, ale również odniesień do wielu innych zagadnień dotyczących Polski i innych krajów”. W szkole ponadgimnazjalnej na lekcjach biologii zaleca się uczniom wykonywanie ćwiczeń oraz dokonywania obserwacji na wycieczce do najbliżej położonego obszaru chronionego. Bezpośrednia obserwacja jest niezbędna przy realizacji tematu z zakresu ochrony ekosystemów. W ramach wspomnianego przedmiotu realizowanego w zakresie rozszerzonym Podstawa programowa... przewiduje co najmniej dwa obligatoryjne zajęcia terenowe „umożliwiające poglądową realizację takich działów, jak ekologia i różnorodność organizmów".

Przytoczone przykłady jednoznacznie wskazują potrzebę zajęć terenowych, szczególnie w obszarach chronionych, m.in. w parkach narodowych. Należy jednak podkreślić, że świadomość ekologiczna społeczeństwa - pomimo intensyfikacji procesu edukacji środowiskowej - wciąż jest bardzo niska. Nie wystarczy już znać i przestrzegać zasady ,przede wszystkim nie szkodzić”. Na problem ten trafnie zwracają uwagę m.in. Z. Wnuk i J. Rut (2000), pisząc: „Około 60\% ludności w Polsce żyje w miastach, w których brak jest związku człowieka z przyrodą. Przyroda dla mieszczuchów stała się czymś obcym, dlatego musimy zrobić wszystko, aby nastąpił powrót do przyrody, organizując autentyczne kontakty. [...] Należy bezpośrednio obcować z nią, oglądać ją i poznawać. Bardzo ważne jest tu uprawianie turystyki przyrodniczej. Zajęcia z przyrody winny odbywać się w terenie na wszystkich szczeblach edukacji”.

\section{EDUKACJA PROWADZONA W PARKACH NARODOWYCH}

Do podejmowania działań edukacyjnych parki narodowe zobowiązane są statutowo. Kształtowanie świadomości ekologicznej wśród społeczności lokalnych, kształtowanie zachowań turystów odwiedzających park oraz przekazanie społeczeństwu odpowiedniego wizerunku parku narodowego - to główne zadania wszelkich zabiegów dydaktycznych tu prowadzonych. „Znaczenie edukacyjnej funkcji parków narodowych - jak ocenia W. Blecharczyk (2000) - wzrosło $\mathrm{z}$ chwilą, gdy uświadomiono sobie, jak wielkie znaczenie $\mathrm{w}$ edukacji ekologicznej ma kontakt z przyrodą". Oferują one odwiedzającym, m.in.: wystawy przyrodnicze i artystyczne, prelekcje, opracowania wydawnicze, debaty oraz pogadanki tematyczne, pokazy filmów, konkursy, rajdy, festyny, happeningi, czy warsztaty terenowe oraz lekcje na ścieżkach dydaktycznych. Propozycje te skierowane są do wszystkich zwiedzających, szczególnie jednak do dzieci i młodzieży. Dodajmy, że czynnikiem, który spotęgował edukacyjny prestiż parków narodowych była reforma systemu szkolnictwa z 1999 roku. Przywróciła ona znaczenie zajęć w terenie, wprowadzając do szkół obligatoryjne 


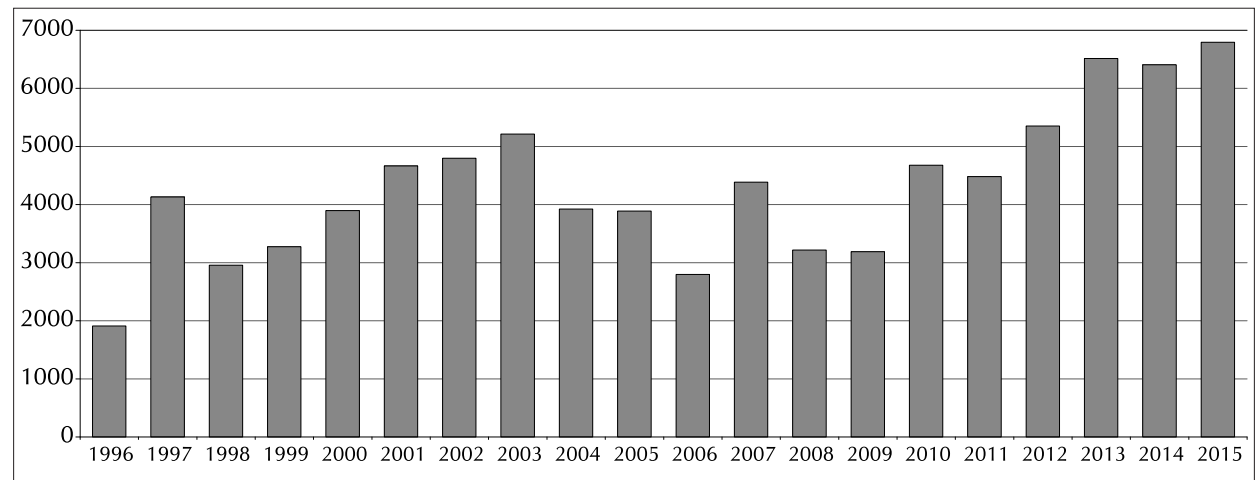

Ryc. 1. Łączna liczba imprez dydaktycznych w parkach narodowych w Polsce w latach 1996-2015 (opracowanie własne na podstawie danych GUS)

Fig. 1. The total number of didactic events in national parks in Poland in 1996-2015

„międzyprzedmiotowe ścieżki edukacyjne”. Wśród nich znalazła się „,́́cieżka ekologiczna", która wymusiła niejako współpracę szkół z parkami narodowymi, gdzie optymalna jej realizacja szczególnie tam mogła być zapewniona (Hibszer 2004, 2005; Wojtanowicz 2014).

Według szacunkowych danych ${ }^{1} \mathrm{z}$ lat 1996-2015, ogółem we wszystkich parkach narodowych w Polsce odbyło się blisko 86500 imprez dydaktycznych. Średnio, na jeden rok analizowanego okresu przypada zatem ponad 4300 imprez. Najwięcej, bo 6795 odbyło się w 2015 roku, a najmniej w 1996 roku - 1910. Wart podkreślenia jest fakt, że w latach objętych badaniem liczba omawianych event'ów ulegała zmianie, w uogólnieniu przyjmując wyraźną tendencję rosnącą (ryc. 1).

Zdecydowanym liderem $\mathrm{w}$ tego typu ofercie edukacyjno-turystycznej jest Kampinoski P.N. (średnio blisko 800 imprez edukacyjnych rocznie). Na miejscu drugim znalazł się Słowiński P.N. (ok. 400 imprez), a na trzecim - Tatrzański P.N. (blisko 320 imprez). Kolejne trzy miejsca, zajmują: Bieszczadzki P.N., Karkonoski P.N. oraz Roztoczański P.N. (średnio po ok. 300 imprez rocznie) (ryc. 2). Według danych GUS rekordowo dużo imprez dydaktycznych miało miejsce w: Tatrzańskim P.N. - 1372 w 2007 r. i 1245 w 2003 r., Bieszczadzkim P.N. - 1284 w 1997 r. i 1271 w 2000 r., Magurskim P.N. - 1215 w 2014 roku i 1170 w 2015

1 Wątpliwości budzić mogą wartości przekazywane do GUS przez dyrekcje parków. W przypadku braku ujednoliconej terminologii oraz zakresu pojęciowego ,imprezy dydaktycznej”, trudno było o jednoznaczną deklarację, czy dany event zaliczyć można było do tegoż działania. Autorzy niniejszego opracowania zgadzają się z S. Liszewskim (2009) w kwestii miarodajności danych źródłowych uzyskanych za pośrednictwem GUS. Choć nie do końca oddają one właściwy wymiar badanego zjawiska, to do analizy ogólnej wydają się wystarczające. 
roku oraz Kampinoskim P.N. - 1128 w 2002 roku i 1070 w 2005 roku. Dodajmy, że w Roztoczańskim P.N. najwięcej imprez o charakterze dydaktycznym odbyło się w 2002 roku - 916, a najmniej w 2007 roku - 63.

D. Matuszewska (1998) doceniając podejmowane w parkach działania edukacyjne, pisała: „Często najzwyklejszy kamień, wygięte drzewo czy zaobserwowane w naturalnych warunkach zwierzę, działa na wyobraźnię człowieka silniej niż dziesiątki stron przewodników oraz podręczników szkolnych". Angażowanie emocjonalne odwiedzających parki narodowe powinno być zatem jedną ze specyficznych cech metodyki ich poznawania. Z kolei „przeżycie przyrody” będzie głębsze, gdy człowiek będzie miał określoną o niej wiedzę (Andrzejewski 1996, Hibszer 2006). W związku z powyższym, zadaniem pracowników ośrodków edukacyjnych przy parkach narodowych jest zachęcanie ludzi, zwłaszcza dzieci i młodzieży, do świadomego zwiedzania parku i podejmowania działań na rzecz ochrony ich przyrodniczych walorów. Ale czy tylko przyrodniczych? Jak słusznie postulowała M. Z. Pulinowa (2000), w parkach narodowych nie wystarczy już edukacja ekologiczna (w rozumieniu: przyrodnicza). Istnieje potrzeba edukacji

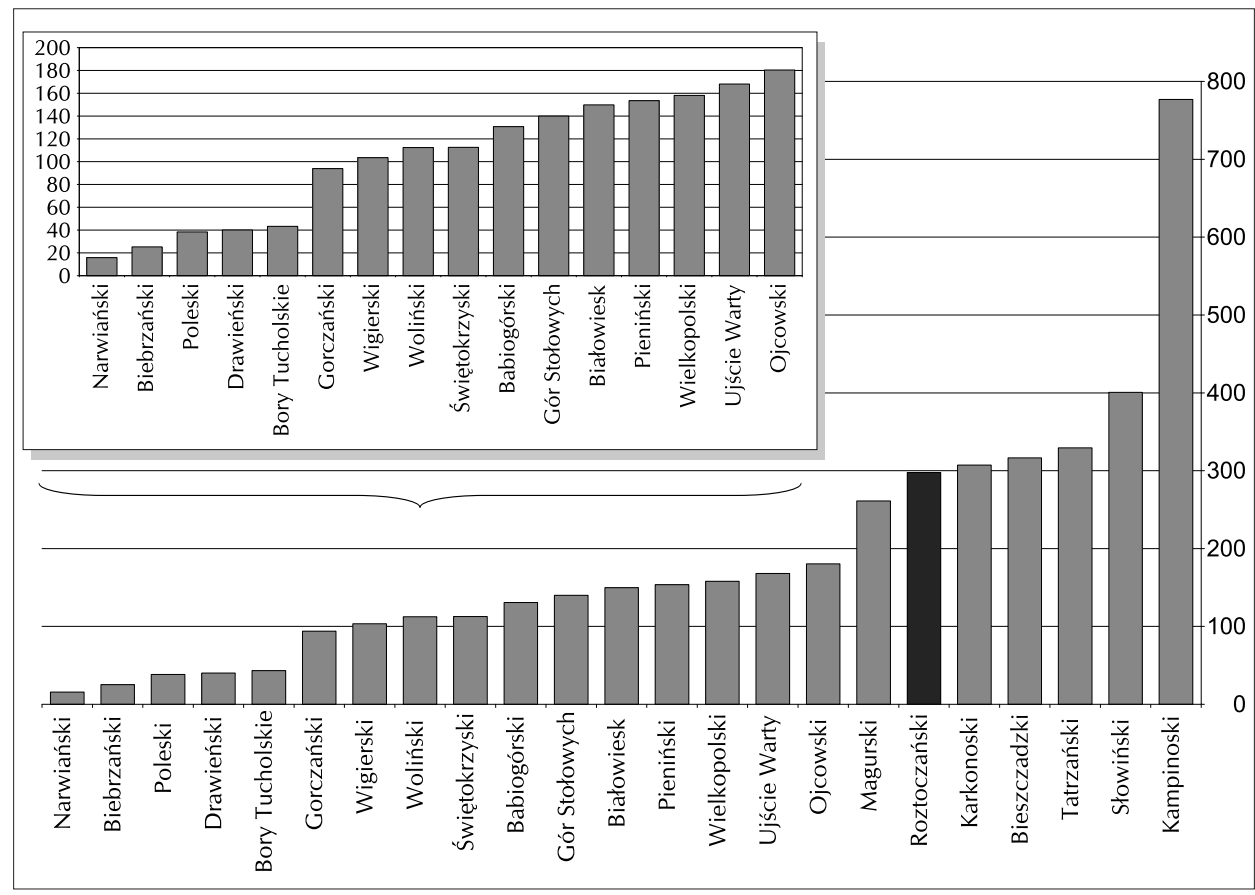

Ryc. 2. Średnia roczna liczba imprez dydaktycznych w parkach narodowych w latach 1996-2015 (opracowanie własne na podstawie danych GUS)

Fig. 2. The average annual number of didactic events in national parks in the years 1996-2015 
holistycznej, tj. całościowego poznania przyrody parku oraz dorobku egzystującego w nim człowieka - dziedzictwa kulturowego.

Obok działalności wystawienniczej w muzeach parków narodowych, do najbardziej tradycyjnych sposobów propagowania dziedzictwa przyrodniczego i kulturowego oraz udostępniania wyników badań naukowych prowadzonych na ich terenie należą wydawnictwa popularnonaukowe. Niemalże każdy park posiada bogaty zasób propozycji edytorskich, do których należą głównie: monografie, opracowania kartograficzne, periodyki, informatory, przewodniki, foldery i broszury, ulotki informacyjne, kalendarze, pocztówki, bądź materiały audiowizualne. Co roku łączna liczba nowych opracowań obejmuje ponad 100 pozycji.

Wspomnieć wreszcie należy, że dzieci uczestnicząc w wydarzeniach turystyczno-edukacyjnych organizowanych przez ośrodki edukacyjne przy parkach narodowych, mogą inspirować rodziców do wspólnych wypraw turystycznych, a tym samym uczestniczyć w procesie pedagogizacji przyrodniczej rodziców. Takie zajęcia terenowe przyczynić się mogą także do propagowania zdrowego stylu życia, a w młodym pokoleniu pozwalają utrwalać aktywności służące kulturze spędzania wolnego czasu (Rut, Wnuk 2000).

\section{OFERTA EDUKACYJNA ROZTOCZAŃSKIEGO PARKU NARODOWEGO}

Obszar Roztoczańskiego Parku Narodowego wraz z jego najbliższym sąsiedztwem, ze względu na bogactwo walorów przyrodniczych i kulturowych od dawna wykorzystywany był w edukacji szkolnej. Sąsiedztwo Zamościa, a także Lublina sprawiło, że był on traktowany jako baza doświadczalna przyrodniczych zajęć terenowych najpierw dla nauczycieli, a później dla samych uczniów. Nie bez znaczenia dla edukacyjnego wykorzystania tego terenu był również fakt włączenia Wyżyny Lubelskiej z Roztoczem do treści programów nauczania geografii (również przyrody) jako przykładowego obszaru wyżynnego w Polsce. Względnie duże wsparcie w realizacji terenowej edukacji po Roztoczańskim Parku Narodowym stanowi tradycyjne przewodnictwo turystyczne, głównie do „pamiątek” po Ordynacji Zamojskiej, jak również do licznych obiektów przyrodniczych zlokalizowanych wzdłuż długiej sieci różnego rodzaju szlaków turystycznych. Należy zatem zwrócić uwagę, że działalność edukacyjna na terenie Roztoczańskiego Parku Narodowego odbywa się w warunkach ukształtowanego już regionu turystycznego.

Roztoczański P.N. realizując cele ochrony zasobów przyrodniczych, krajobrazowych i kulturowych, od początku swego istnienia podejmował wiele działań związanych z działalnością edukacyjną. Jednak dopiero od 1994 roku 
działania te mają charakter bardziej ukierunkowany, kiedy oddano Ośrodek Edukacyjno-Muzealny Roztoczańskiego (OEM) P.N. w Zwierzyńcu. Udostępnianiu terenu parku dla turystyki oraz prowadzeniu w nim działalności edukacyjnej obok wspomnianego wyżej obiektu służą: Roztoczańskie Centrum Naukowo-Edukacyjne oraz terenowe bazy edukacyjne: Izba Leśna, Gajówka Krzywe, Gajówka Komanówka oraz Gajówka Wojda. Jedną z głównych ofert edukacyjnych parku jest organizowanie wystaw stałych oraz wystaw czasowych. $\mathrm{Na}$ szczególną uwagę zasługuje stała (od 2009 roku) wystawa przyrodnicza pt. W krainie jodty, buka i tarpana składająca się z 11 dioram. Obraz wzbogacony scenografią, świattem i dźwiękiem zabiera turystów w świat przyrody Roztocza. Z kolei we Floriance, przykładając wielką wagę do spuścizny kulturowej regionu, udostępniono Izbę Leśną, którą odtworzono na podstawie zabudowań gajówki z czasów Ordynacji Zamojskiej. Ekspozycję stałą (w tym: zrekonstruowaną kancelarię leśniczego według stanu z 1938 roku) w wyżej wspomnianym obiekcie, uzupełniają zabudowania gospodarcze, w których zorganizowano letnią salę z zapleczem edukacyjnym.

W parku, z myślą o turystyce szkolnej, realizowane były programy edukacyjne (np. Roztoczański Park Narodowy i My, Poznajemy polskie parki narodowe) oraz pakiety/moduły edukacyjne (np.: Odkryj, zobacz i poznaj, Przyrodniczy kalejdoskop RPN, Sekrety natury, Roztaczamy swoje horyzonty). Dla dzieci i uczniów z okolicznych przedszkoli oraz szkół podstawowych i gimnazjalnych współpracujących z parkiem organizowane były zajęcia edukacyjne zarówno kameralne, jak i terenowe (np.: Poznajemy przyrode RPN, Moje drzewo, Moje 10 pytań do lasu, Powiąania biocenozy lasu ze środowiskiem nieożywionym, na przykładzie zależności szaty roślinnej od rodzaju podłoża, Przyrodnicze koło fortuny, Wąwóz lessowy, Poszukiwanie relacji pomiędzy wydma a otoczeniem, Historia wpisana w nazwy miejscowości Zwierzyniec, Poznajemy tajemnice Roztocza i przeszłość Zwierzyńca, Cechy krajobrazu naturalnego i kulturowego wzdtuż trasy...), różnego rodzaju konkursy (np.: konkurs plastyczny Śladami A. Wachniewskiej malarki i orędowniczki ochrony przyrody na Roztoczu, konkurs poetycki Przyroda jaka znam, konkurs fotograficzny Roztocze w obiektywie), przeglądy, plenery, warsztaty, jak również masowe imprezy edukacyjne (np.: Dzień otwarty RPN, Sprzątamy $R P N)$. Dzieci chętnie uczestniczą w wyżej wymienionych zajęciach. Wykazując się kreatywnością oraz zdolnościami artystycznymi, odkrywają one problemy związane z przyrodą parku oraz tradycjami regionu.

Ośrodek Edukacyjny Roztoczańskiego P.N., przykładając dużą wagę do współpracy ze szkołami z regionu oraz z najbliższego sąsiedztwa parku, oferuje nauczycielom gotowe scenariusze ułatwiające samodzielne prowadzenie zajęć. Przykładem takiego rozwiązania jest względnie nowy pakiet materiałów 


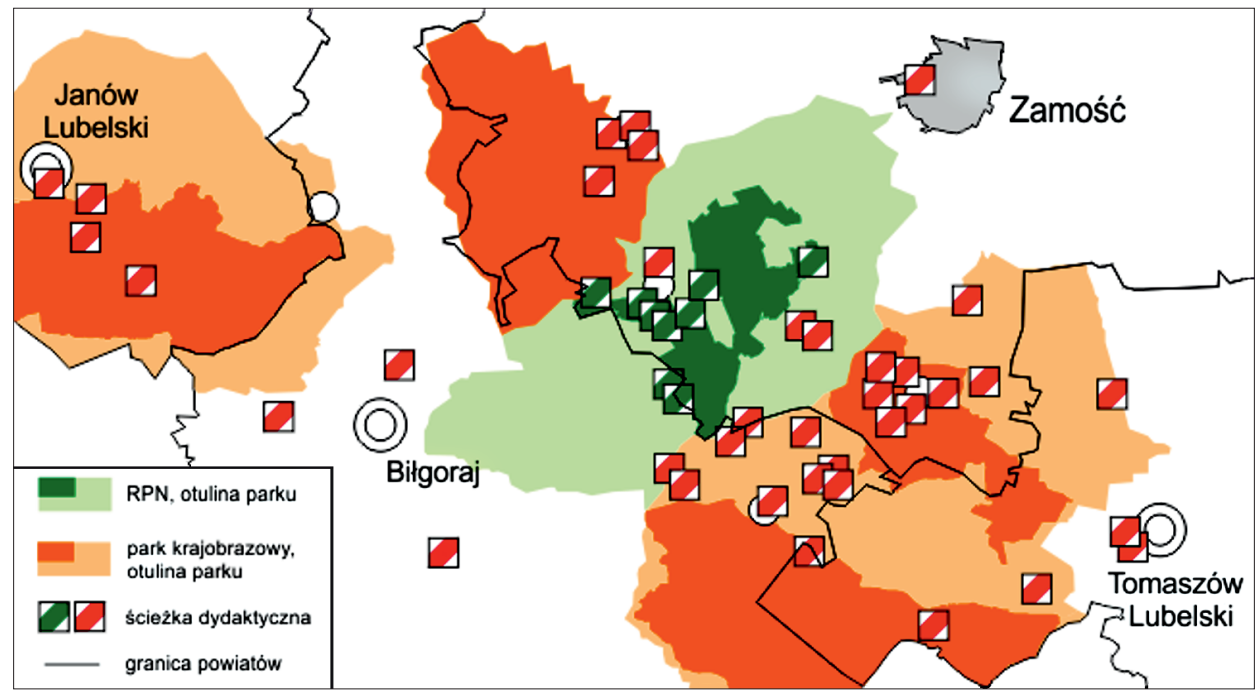

Ryc. 3. Szkic lokalizacyjny ścieżek dydaktycznych w RPN oraz jego najbliższej okolicy (opracowanie własne)

Fig. 3. The location sketch of educational paths in the Roztocze National Park and it's the nearest area

edukacyjnych „Bioróżnorodność wokół nas”2. Tematyka poruszana w udostępnianych konspektach, dostosowana do każdego z poziomów nauczania, jest zróżnicowana. Scenariusze obejmują przede wszystkim zagadnienia dotyczące ochrony przyrody z elementami geografii, botaniki i zoologii. Nauczyciel znajdzie w nich informacje o funkcjonowaniu ekosystemów leśnych, ochronie krajobrazu, przeszłości geologicznej Roztocza oraz historii Zwierzyńca. Materiały niejednokrotnie mają charakter interdyscyplinarny, co sprzyja pogłębieniu w świadomości uczestników myśli, że skuteczna ochrona przyrody wymaga wiedzy oraz umiejętności pochodzących z różnych dziedzin.

Istotnym elementem działalności edukacyjnej parku są również zajęcia na ścieżkach dydaktycznych. Lekcje prowadzone na tych specyficznych formach szlaków turystycznych (w sumie jest ich dziewięć - ryc. 3) zaopatrzonych $\mathrm{w}$ instruktaż dydaktyczny, są pozytywnie odbierane przez dzieci i młodzież. Na większości ścieżek dydaktycznych Roztoczańskiego P.N. nie ma wielu tablic. Jeśli są, to funkcjonują one jedynie na początku bądź końcu danej ścieżki,

2 Wydawnictwo zrealizowane w 2014 roku w ramach projektu „Poznawanie i popularyzacja różnorodności biologicznej Roztocza - regionu pogranicza przyrodniczo-kulturowego", korzystającego z dofinansowania pochodzącego z Islandii, Liechtensteinu i Norwegii w ramach funduszy EOG. 
zawierając ogólne informacje. Wyjątek stanowi ścieżka dendrologiczna we Floriance, gdzie umieszczono wiele tablic informacyjnych prezentujących ponad 60 gatunków drzew i krzewów iglastych i liściastych. Z kolei na ścieżce $\mathrm{Na}$ Bukowa Górę, pozwalającej między innymi poznać najciekawsze zbiorowiska leśne parku (tj. bór jodłowy i buczynę karpacką) obrano inną strategię. Uczniowie na podstawie funkcjonującego systemu numeracji w terenie, równocześnie dysponując drukowanym przewodnikiem, mogą odczytać z niego informacje na temat otaczającego go krajobrazu.

Dodać należy, że szkolny ruch turystyczny w Roztoczańskim P.N. cechuje sezonowość. Najwięcej zwiedzających notuje się w maju, czerwcu i w październiku. Dominują wówczas wycieczki szkolne. Zajęcia z dziećmi i młodzieżą prowadzone są nie tylko w trakcie roku szkolnego. Podczas wakacji oraz w czasie ferii zimowych odbywa się szereg zajęć głównie dla mieszkańców pochodzących z najbliższych okolic parku.

Z dokonanego powyżej ogólnego przeglądu działalności edukacyjnej Roztoczańskiego P.N. wynika, że jest ona niezwykle bogata i bardzo zróżnicowana. Stale rosnąca różnorodność wyżej wymienionych propozycji i form edukacji, będąc zjawiskiem niezmiernie pozytywnym, wymaga jednak ciągłej ,aktualizacji” wynikającej między innymi z kolejnych Podstaw programowych ksztatcenia ogólnego... (2012, 2014, 2017) wynikających z wprowadzanych reform edukacji. Należy zaznaczyć, że ośrodek edukacyjny funkcjonujący przy Roztoczańskim P.N. rozumie znaczenie szkolnych zajęć terenowych i co najistotniejsze wywiązuje się z obowiązku aktualizacji potrzeb swego głównego odbiorcy.

\section{PODSUMOWANIE}

Edukacja w terenie jest istotnym elementem strategii dydaktyczno-wychowawczej we współczesnej szkole. Muszą to być jednak działania przemyślane, które przede wszystkim zaktywizują uczniów, zainteresują ich poruszanymi zagadnieniami, tym samym wywołają emocje, które rozwiną w nich potrzebę czynienia dobra w otaczającej ich rzeczywistości. Podjęta w niniejszym opracowaniu próba oceny działalności edukacyjnej Roztoczańskiego P.N. na rzecz formalnego kształcenia szkolnego pozwala na sformułowanie kilku wniosków, do których przede wszystkim należą:

1. Pełna realizacja celów edukacyjnych zawartych w Podstawie programowej ksztatcenia ogólnego... (szczególnie z 2017 r.) bez zajęć terenowych NIE JEST możliwa.

2. Edukacja środowiskowa, a szczególnie ochrona środowiska jak również edukacja na rzecz zrównoważonego rozwoju są ważnymi zadaniami 
dydaktyczno-wychowawczymi współczesnej szkoły. Właściwym podmiotem do ich realizacji wydają się między innymi parki narodowe.

3. Edukacja przyrodnicza prowadzona przez zespół pracowników Roztoczańskiego P.N. przez ponad 40 lat utrzymuje się na względnie wysokim poziomie. Edukatorzy nie ograniczają się jedynie do powierzchownego poznania rzeczywistości. Mają jednak wyczucie oraz świadomość uwarunkowań percepcji młodych odbiorców oraz faktu, że istnieje granica natężenia uwagi oraz percepcji warunkujące skuteczność procesu poznawczego.

4. Działalność edukacyjna Roztoczańskiego P.N. stwarza szansę nie tylko głębszego poznania środowiska przyrodniczego regionu, ale także daje możliwość rozpoznania pasji, rozwijania uzdolnień, zamiłowań i wrażliwości estetycznej uczniów, rozbudzania ich ciekawości oraz inspiracji do twórczej aktywności.

5. W celu ,pielęgnacji” tego, co zasiane u dzieci najmłodszych, ofertę edukacyjno-turystyczną parku należy uzupełnić o propozycję skierowaną do szerszej grupy odbiorców w szczególności do młodzieży licealnej.

6. Programy większości pakietów edukacyjnych Roztoczańskiego P.N. są mało urozmaicone treściowo, skoncentrowane są na poznaniu jednego typu atrakcji, w szczególności związanego ze środowiskiem przyrodniczym. W celu tak zwanej „edukacji holistycznej” istnieje potrzeba wzbogacenia oferty edukacyjnej Roztoczańskiego P.N. o kolejne elementy historyczno-kulturowe dziedzictwa krajobrazowego parku.

7. Strategia kształcenia przyjęta przez edukatorów Ośrodka Edukacyjnego Roztoczańskiego P.N. powinna być poddawana systematycznej ewaluacji. Nie jest to jednak proces łatwy. Trzeba mieć na uwadze, że efektywność zajęć w krótkim czasie nie jest mierzalna. Na jej skutki w postaci właściwych postaw oraz zachowań odbiorców należy poczekać kilka, kilkanaście lat.

8. Oferta powinna wpisać się w rzeczywiste potrzeby nauczycieli i uczniów, biorąc pod uwagę przede wszystkim możliwość realizacji treści Podstawy programowej..., jak również możliwości i ograniczenia konkretnych placówek szkolnych.

9. Warte przemyślenia jest podjęcie długofalowej współpracy w dziedzinie dydaktyki zajęć terenowych z nauczycielami oraz przedstawicielami jednostek uczelni wyższych. Wymiana myśli w wyżej wymienionej kwestii pomiędzy przedstawicielami różnych środowisk zaowocować może nowymi rozwiązaniami metodycznymi.

10. Nie ma potrzeby wzrostu liczby ścieżek dydaktycznych w Roztoczańskim P.N. Nie bez znaczenia są jednak wyznaczone na nich punkty postojowe. Dłuższy, wynikający z odpowiednio skonstruowanych zadań dydaktycznych, pobyt w wyznaczonych do tego celu miejscach umożliwiłby uczniom bardziej świadome odkrycie elementów poznawanej rzeczywistości oraz zrozumienie 
genezy, przebiegu i skutków procesów, a także przemian krajobrazowych w niej zachodzących.

11. Powszechna dostępność do współczesnych technologii informacyjnych wcale nie musi zagrażać aktywnemu uczestnictwu dzieci i młodzieży w zajęciach terenowych. Wręcz przeciwnie stanowi istotną formę wsparcia oferty zaproponowanej przez edukatora w realnym środowisku przyrodniczo-kulturowym Roztoczańskiego P.N. Dobrymi rozwiązaniami w tym kierunku mogą być np.: geocaching lub questing rozwiązywany z wykorzystaniem Q-kodów.

12. Roztoczański P.N. cieszący się renomą edukacyjną powinien być poddany dalszemu procesowi modernizacji. Nowa oferta edukacyjna powinna ulec dywersyfikacji w kierunku rozwoju aktywizujących strategii wykorzystujących walory nie tylko samego parku, ale także obszarów bezpośrednio z nim sąsiadujących.

\section{LITERATURA}

Alejziak W., 2009: Krajoznawstwo i turystyka szkolna w obliczu wyzwań XXI wieku oraz kształtowania się społeczeństwa wiedzy, [w:] K. Denek, L. Drożdżyński, A. Gordon (red.), O potrzebie krajoznawstwa w edukacji szkolnej, AW „Delta”, Wydawnictwo PTTK „Kraj”, Warszawa-Poznań, 67-80.

Andrzejewski R., 1996: Parki narodowe a dydaktyka, Parki Narodowe, 4, 4-5.

Batorowicz Z., 1966: Wycieczki szkolne, [w:] J. Barbag (red.), Metodyka nauczania geografii, PZWS, Warszawa, 227-248.

Berne I., 1977: Zajęcia w terenie. Poradnik dla nauczycieli geografii „Z moich doświadczeń”, WSiP, Warszawa.

Blecharczyk W., 2000: Integracyjna i edukacyjna rola systemu ochrony przyrody w parkach narodowych i krajobrazowych, [w:] Z. Wnuk i in. (red.), Turystyka w parkach narodowych. Materiały IV Krajowej Konferencji „, Ochrona przyrody a turystyka”, WSP, Rzeszów, 97-101.

Bochenek M., 2008: Turystyka w edukacji dzieci i młodzieży, Monografie i Opracowania nr 4. AWF Warszawa, Zam. WWF, Biała Podlaska.

Chałubińska A., 1959: Różne drogi nauczania geografii, PZWS, Warszawa.

Czekańska M., 1963: Zarys metodyki geografii, PZWS, Warszawa.

Denek K., 1996: Na turystycznych szlakach Polski, Wyd. A. Marszałek, Torun.

Denek K., 1999: Krajoznawstwo i turystyka dzieci i młodzieży - okazją do współdziałania, samorządności i demokracji, Lider, 7-8, 12-15.

Hibszer A., 2004: Empiryczny wymiar edukacji przyrodniczej na przyktadzie Wyżyny Krakowsko-Częstochowskiej, [w:] J. Partyka (red.), Zróżnicowanie i przemiany środowiska przyrodniczo-kulturowego Wyżyny Krakowsko-Częstochowskiej, t. 2, Kultura, OPN, Ojców, 351-356.

Hibszer A., 2005: Funkcja edukacyjna parków narodowych oraz jej rola w zapobieganiu konfliktom - zarys problemu, [w:] A. Hobszer, J. Partyka (red.), Między ochrona przyrody a gospodarka - blizej ochrony. Konflikt czlowiek - przyroda na obszarach prawnie chronionych w Polsce, Oddział Katowicki PTG, OPN, Sosnowiec-Ojców, 214-224. 
Hibszer A., 2006: O potrzebie ewaluacji zajęć w ośrodkach edukacyjnych parków narodowych, [w:] 15 lat ośrodków edukacyjnych w parkach narodowych, 33-43.

Janowski I., 2004: Wycieczki szkolne, Instytut Geografii Akademii Świętokrzyskiej, Kielce.

Kądziołka J., 1992: Wycieczki szkolne, [w:] S. Piskorz (red.), Zarys dydaktyki geografii, WSiP, Warszawa, 204-212.

Liszewski S., 2009: Przestrzeń turystyczna parków narodowych w Polsce, [w:] B. Domański, W. Kurek (red.), Gospodarka i przestrzeń, Instytut Geografii i Gospodarki Przestrzennej UJ, Kraków, 187-201.

Lutz F. (1931) Nature trails an experiment in out-door education, Miscellaneous Publications No. 21 of The American Museum of Natural History (second edition), New York.

Łobożewicz W. i T., 1978: Wycieczka - podstawowa forma pracy krajoznawczo-turystycznej szkoły, [w:] W. i T. Łobożewicz (red.), Krajoznawstwo i turystka w szkole, WSiP, Warszawa, 94-137.

Matuszewska D., 1998: Chronimy mądrze - edukacja i dydaktyka w polskich parkach narodowych, Parki Narodowe, $1,7$.

Nałkowski W., 1908: Środki i sposoby nauczania geografii. Rozdział III Zarysu metodyki geografi, [w:] W. Nałkowski (red.), Dydaktyka geografii, PZWS, Warszawa, 114-132.

Niemcówna S., 1929: Dydaktyka geografii, Książnica-Atlas, Lwów-Warszawa.

Pawłowski S., 1933: Wskazówki Metodyczne do podręcznika Geografja Polski dla I klasy gimnazjalnej, Książnica-Atlas, Lwów-Warszawa.

Podstawa programowa kształcenia ogólnego..., [w:] Rozporządzenie Ministra Edukacji Narodowej z dnia 27 sierpnia 2012 r. w sprawie podstawy programowej wychowania przedszkolnego oraz kształcenia ogólnego w poszczególnych typach szkół (Dz. U. poz. 977); Rozporządzenie Ministra Edukacji Narodowej z dnia 30 maja 2014 r. zmieniające rozporządzenie w sprawie podstawy programowej wychowania przedszkolnego oraz kształcenia ogólnego w poszczególnych typach szkół (Dz. U. poz. 803); Rozporządzenie Ministra Edukacji Narodowej z dnia 14 lutego 2017 roku w sprawie podstawy programowej... (Dz. U. 2017, poz. 356).

Pulinowa M. Z., 2000: O harmonijne taczenie edukacji przyrodniczej i kulturowej w parkach narodowych, Krajobrazy Dziedzictwa Narodowego, 3, 41-46.

Rut J., Wnuk Z., 2000: Funkcje edukacyjne turystyki, [w:] Z. Wnuk i in. (red.), Turystyka w parkach narodowych, Materiały IV Krajowej Konferencji „Ochrona przyrody a turystyka”, WSP, Rzeszów, 103-107.

Szuman S., 1985: Studia nad rozwojem psychicznym dziecka, WSiP, Warszawa.

Świtalski E., 1990: Wycieczki szkolne, [w:] A. Dylikowa (red.), Dydaktyka geografii w szkole podstawowej, WSiP, Warszawa, 305-313.

Winklewski J., 1966: Wycieczki w nauczaniu geografii, [w:] J. Winklewski (red.), Metodyka nauczania geografii dla studiów nauczycielskich, PZWS, Warszawa, 213-226.

Wnuk Z., Rut J., 2000: Turystyka w Magurskim Parku Narodowym, [w:] Z. Wnuk i in. (red.), Turystyka w parkach narodowych, Materiały IV Krajowej Konferencji „Ochrona przyrody a turystyka", WSP, Rzeszów, 123-151.

Wojtanowicz P., 2014: Typologizacja i periodyzacja rozwoju ścieżek dydaktycznych $w$ Polskich parkach narodowych, Folia Turistica, 30, 27-54.

Wuttke G., 1963: Ćwiczenia i wycieczki w nauczaniu geografii, PZWS, Warszawa. 


\section{SUMMARY}

Article presents educational offer in Roztocze National Park. It includes purposes of education from range of objects: nature, geography and biology. Results of research indicate that educational activity not only deepens the knowledge of environment of the natural region of RPN. It also makes possible deployment of talent, passions and esthetic sensitivity of the pupil, awaking of curiosity and creative activity. For holistic education, the authors draw attention to the need to increase the educational offer with further cultural elements of the park. 